\title{
A new cave species of Rhamdia (Siluriformes: Heptapteridae) from Serra do Ramalho, northeastern Brazil, with notes on ecology and behavior
}

\author{
Maria Elina Bichuette and Eleonora Trajano
}

Rhamdia enfurnada, a new troglobitic (exclusively subterranean) catfish, is described from the Gruna do Enfurnado, Serra do Ramalho, southwestern Bahia State, middle São Francisco River basin. It differs from epigean congeners from the São Francisco River basin by the variable eye size, ranging from reduced to externally invisible (bilateral asymmetry in development of eyes is frequently observed), with a conspicuous orbital concavity (orbital diameter varying from 6.4 to $13.6 \%$ of head length in R. enfurnada and from 14.5 to $24.4 \%$ in the epigean species); by the dark pigmentation reduced due to a decrease in density of melanophores, and also variable. In comparison to other cave species, $R$. enfurnada presents a low degree of troglomorphism regarding development of eyes and pigmentation, indicating a relatively short time evolving in isolation in the subterranean environment: $R$. reddelli is described as lacking eyes and with almost no pigmentation; likewise, $R$. macuspanensis and $R$. laluchensis as having rudimentary eyes, covered with skin and not visible externally, and with reduced body pigmentation; $R$. zongolicensis is also almost devoid of dark pigmentation, but eyes are less reduced than in $R$. reddelli. $R$. quelen urichi, also does not present any trace of eyes externally, but the body coloration is described as pale yellowish brown. Rhamdia guasarensis has a concave dorsal profile of head and a complete absence of pigmentation and eyes. The population density (preliminarily estimated in 0.1-0.2 individuals $\mathrm{m}^{-2}$ in average, and reaching 10 individuals $\mathrm{m}^{-2}$, in the dry season and size (several thousands of individuals) of $R$. enfurnada may be considered high for cave fish standards. Rhamdia enfurnada exhibited an increased midwater activity when compared to their typically bottom-dwelling epigean relatives; are mostly indifferent to light and moderately aggressive.

Rhamdia enfurnada, uma nova espécie de bagre troglóbio (exclusivamente subterrâneo), encontrada na Gruna do Enfurnado, Serra do Ramalho, sudoeste Baiano, Bacia do Médio Rio São Francisco, é aqui descrita. Esses bagres diferem dos congêneres com ocorrência em rios epígeos da bacia do São Francisco pela alta variabilidade no grau de desenvolvimento dos olhos, de apenas ligeiramente reduzidos até externamente invisíveis, com freqüente assimetria bilateral (diâmetro da órbita: comprimento da cabeça variando de 6,4 a 13,6\% em $R$. enfurnada e de 14,5 a 24,4\% nos espécimes epígeos examinados); pela pigmentação melânica reduzida devido à diminuição na densidade de melanóforos, também com variação populacional. Comparando-se com outras espécies cavernícolas, $R$. enfurnada apresenta um baixo grau de troglomorfismo, em relação aos olhos e pigmentação, indicando um tempo de isolamento no ambiente subterrâneo relativamento pequeno: $R$. reddelli não possui olhos e pouca pigmentação no corpo; da mesma maneira, R. macuspanensis e $R$. laluchensis apresentam olhos rudimentares, cobertos por pele e não visíveis externamente, além de pigmentação reduzida no corpo; $R$. zongolicensis quase não apresenta pigmentação no corpo. Rhamdia quelen urichi, também não possui traços de olhos visíveis externamente, mas a coloração do corpo é pálida, marrom-amarelada. Rhamdia guasarensis apresenta uma cabeça com perfil côncavo e olhos e pigmentação completamente ausentes. As densidades populacionais (preliminarmente estimada entre 0.1-0.2 indivíduos $\mathrm{m}^{-2}$, e atingindo até 10 indivíduos $\mathrm{m}^{-2}$, na estação seca) e tamanhos populacionais (milhares de indivíduos) de $R$. enfurnada podem ser considerados altos para padrões de organismos cavernícolas. Rhamdia enfurnada apresenta um aumento de natação na coluna d'água comparandose com os parentes epígeos, os quais apresentam tipicamente natação no fundo; apresentam indiferença à luz e são moderadamente agressivos.

Key Words: Subterranean catfishes, Rhamdia enfurnada, Bahia, São Francisco River basin, Taxonomy.

Departamento de Zoologia, Instituto de Biociências da USP, Caixa Postal 11461, 05422-970 São Paulo, SP, Brazil. e-mail: bichuette@uol.com.br; etrajano@usp.br 


\section{Introduction}

The generally nocturnal, chemoriented Siluriformes present a high potential for life in subterranean habitats, characterized by the permanent darkness and frequent food limitation. Among catfishes, the generalist heptapterids include a significant number of exclusively subterranean species (troglobites) in the neotropics, such as the cave-dwelling Pimelodella kronei (Miranda Ribeiro, 1907), P. spelaea Trajano, Reis \& Bichuette, 2004, Taunayia sp. and a new, undescribed genus, from Brazil, and several species from Mexico, Belize, Trinidad Island, and Venezuela (Weber et al., 1998; DoNascimiento et al., 2004). These troglobitic species differ in their degree of reduction of eyes and dark pigmentation, the most conspicuous characters related to the isolation in the subterranean environment (troglomorphisms), from species with only slightly reduced eyes and pigmentation, such as $P$. spelaea, to those totally anophthalmic and unpigmented, such as Taunayia sp. and a new heptapterid genus, passing through species showing intrapopulational variation in these characters (e.g., P. kronei).

Troglobitic Rhamdia catfishes encompass at least eight taxa: $R$. quelen urichi (= Caecorhamdia urichi Norman, 1926), R. laticauda typhla Greenfield, Greenfield \& Woods, 1982, $R$. reddelli Miller, 1984, $R$. zongolicensis Wilkens, 1993, $R$. macuspanensis Weber \& Wilkens, 1998, R. laluchensis Weber, Allegrucci \& Sbordoni, 2003, R. guasarensis DoNascimiento, Provenzano \& Lundberg, 2004, from Venezuela, and the species described herein from Brazil. Due to lack of explicit diagnoses between named forms, Silfvergrip (1996) chose to synonymize $R$. zongolicensis, $R$. reddelli, and Rhamdia laticauda typhla to the epigean species $R$. laticauda, and $R$. quelen urichi to Rhamdia quelen, regarding the troglomorphic populations of cave forms of the two epigean relatives, respectively. Because these subterranean taxa may be distinguished from related epigean forms on the basis of at least the reduction of eyes and pigmentation, indicating isolation in subterranean habitats, and following recent authors as Romero \& Paulson (2001) and Weber et al. (2003), we do not follow the synonymy proposed by Silfvergrip (1996).

Rhamdia catfishes are nocturnal, opportunistic carnivores, thus it is not surprising to find them in the subterranean environment. In fact, this genus is included among those found in caves throughout the world with the highest number of troglobitic derivatives, together with Trichomycterus (Siluriformes: Trichomycteridae; at least seven species), Sinocyclocheilus (Cypriniformes: Cyprinidae; seven species) and Lucifuga (Ophidiiformes: Bythitidae; five species) (Weber et al., 1998; Trajano \& Bichuette, unpubl. data).

Rhamdia catfishes belonging to epigean (surface) species have been observed in several Brazilian caves, usually as isolated or few individuals (e.g., Trajano, 1991, for the upper Ribeira River valley, southeastern Brazil; Bichuette \& Trajano, 2003, for São Domingos karst area, central Brazil; E. Trajano \& M. E. Bichuette, pers. obs., for caves from
Varzelândia and Cordisburgo, eastern Brazil). Most of these individuals were apparently in good condition and could have been feeding in the subterranean habitat, but there was no good evidence of reproduction in the caves - these records probably represent trogloxenes (organisms found regularly in subterranean habitats but which do not complete their life cycle in this environment - Trajano, 2003). So far, there was no indisputable record of reproductive, self-sustained subterranean populations of Rhamdia catfishes in Brazil, either troglophilic (belonging to species found both in epigean and subterranean habitats) or troglobitic (exclusively subterranean).

Two new species of troglomorphic catfishes, pertaining to the genera Trichomycterus (cited as Trichomycterus sp. 3 in Trajano, 2003) and Rhamdia, have been found in caves of the recently explored Serra do Ramalho karst area (southwestern State of Bahia). This area presents a great biospeological potential, with several large cave systems in the process of being explored and mapped, with remarkable terrestrial troglobites that include the first troglobitic Amblypygi recorded for Brazil (Charinus troglobius Baptista \& Giupponi, 2003), a highly troglomorphic genus of gonyleptid harvestman (Giupponia chagasi Pérez \& Kury, 2002) and a new genus of spider (Ochyroceratidae) with modified genitalia, under description (R.L. Baptista, pers. comm.). The new Rhamdia species was found in the Gruna do Enfurnado and is characterized by the large population size and the high individual variability in the degree of development of eyes and pigmentation.

We herein describe this new species, which represents the first troglobitic Rhamdia known from Brazil. Preliminary data on the ecology and behavior of these catfishes are also presented.

\section{Material and Methods}

Measurements and meristic data for the type series of $R$. enfurnada (20 specimens) were taken following Lundberg \& McDade (1986) and Bockmann (1994), respectively. For comparison, the same variables were obtained from 19 specimens of epigean Rhamdia from the São Francisco River basin (see Comparative Material Examined). All measurements were taken on the left side of the specimens using a Mitutoyo digital caliper ( $0.1 \mathrm{~mm}$ precision). For the osteological study, two paratypes ( 99.6 and $58.9 \mathrm{~mm} \mathrm{SL}$ ) were cleared and stained using the method of Taylor \& Van Dyke (1985). These two specimens were used for counting the number of vertebrae, ribs, branchiostegal rays and serrae of the pectoral-fin spine. In addition, the stomach contents of these two individuals were examined. The vertebrae counts included all free vertebrae posterior to the Weberian complex and the compound caudal centrum (counted as one). The degree of body pigmentation was evaluated by counting the number of melanophores in a $1 \mathrm{~mm}^{2}$ area below the dorsal fin, on the left side of three cave and three epigean specimens. 
For comparisons of morphometric proportions, we used the two sample t-test (for parametric data) or the MannWhitney test ( $\mathrm{T}$ test, when data was non-parametric), with á $=5 \%$ (SigmaStat, version 2.0). Data from ecological study (July 2005) were used to build histograms showing the distribution of standard length.

Institutional and other abbreviations: LIRP, Laboratório de Ictiologia de Ribeirão Preto, Universidade de São Paulo, Ribeirão Preto; MZUSP, Museu de Zoologia da Universidade de São Paulo, São Paulo; SL, standard length; HL, head length; c\&s, cleared and stained.

\section{Rhamdia enfurnada, new species}

Fig. 1

Holotype. MZUSP 87776, 137.8 mm SL, Brazil, southwestern State of Bahia, Serra do Ramalho, Município de Coribe, Povoado de Descoberto, Gruna do Enfurnado (13³8'44"S 44 ${ }^{\circ} 12^{\prime}$ '05.9"W, elevation 628 m), middle São Francisco River basin; E. Trajano \& M.E. Bichuette, 5 Sep 2003.

Paratypes. MZUSP 87777 (13 exs.), 50.5-218.5 mm SL; MZUSP 87778 (1 ex., c\&s), 58.9 mm SL; MZUSP 87779 (1 ex., c\&s), 99.7 mm SL; and LIRP 5643 (4 exs.), 43.8-147.1 mm SL, all collected with the holotype.

Diagnosis. Rhamdia enfurnada differs from its epigean congener (Rhamdia cf. quelen) from the São Francisco River basin by the highly variable eye size, ranging from reduced to
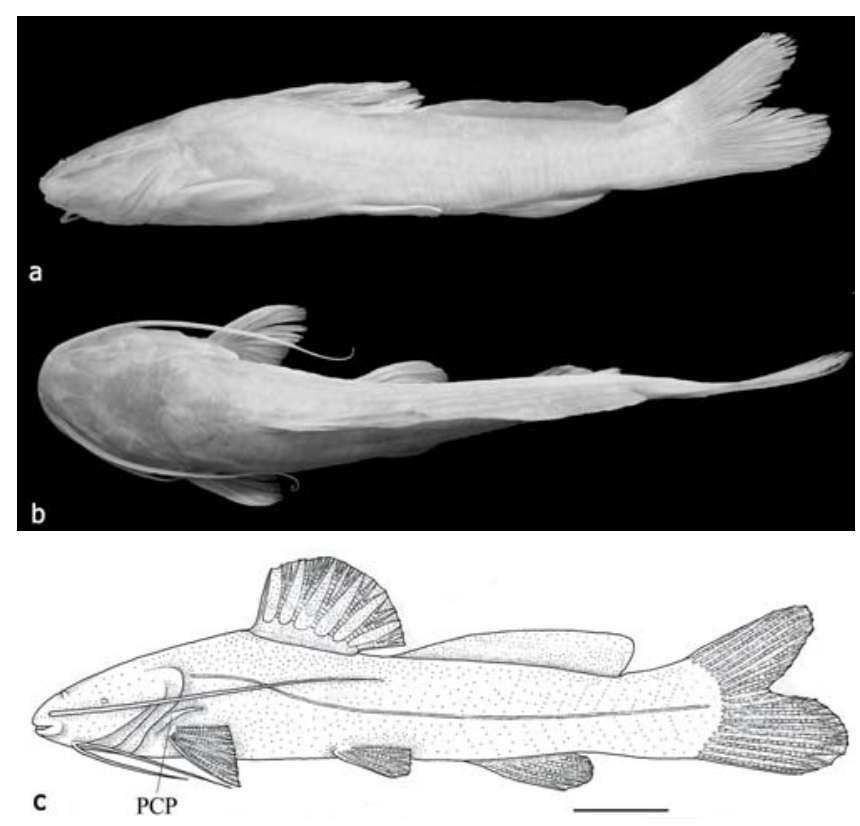

Fig. 1. Rhamdia enfurnada from Gruna do Enfurnado, Bahia State, northeastern Brazil; a, b, holotype, MZUSP 87776, 137.8 $\mathrm{mm} \mathrm{SL}$, in lateral and dorsal views, respectively; c, holotype, detail showing the long posterior-cleithral process (PCP). Scale bar, $20 \mathrm{~mm}$. Drawing: F. D. Passos. externally invisible, with an open orbital concavity (orbital diameter varying from 6.4 to $13.6 \%$ of head length in $R$. enfurnada and from 14.5 to $24.4 \%$ in the epigean species); eyes, when present, pigmented and covered by semi-opaque skin, orbital rim absent or poorly developed in most specimens, well-defined only in some small specimens; dark pigmentation reduced due to a decrease in density of melanophores; and iridorophores present and concentrated in the opercular region. In comparison to other troglobitic Rhamdia species, R. enfurnada exhibits a lower degree of troglomorphy regarding eyes and pigmentation, which are highly variable; Rhamdia reddelli is described as lacking eyes and with almost no pigmentation; likewise, $R$. macuspanensis and $R$. laluchensis as having rudimentary eyes, covered with skin and not visible externally, and with reduced body pigmentation; Rhamdia zongolicensis is also almost devoid of dark pigmentation, but eyes are less reduced than in $R$. reddelli. Rhamdia quelen urichi, from Trinidad, also does not exhibit any trace of eyes externally, but the body coloration is described as pale yellowish brown. Rhamdia enfurnada has a concave dorsal profile of the head and a complete absence of pigmentation and eyes. Variability in development of eyes and pigmentation as in $R$. enfurnada was only reported for Rhamdia laticauda typhla, from Belize.

Description. Morphometric data in Table 1. Distribution of standard length classes relative to 121 individuals measured under anesthesia and released in July 2005 during ecological study presented in Fig. 2.

Body elongated, its greatest depth at vertical passing by dorsal-fin origin (Fig. 1a). Dorsal profile anterior to dorsal fin slightly to distinctively convex, then descending to caudal peduncle, slightly concave between dorsal and adipose fins. Head depressed, broad and relatively short, trapezoidal in dorsal profile. Largest specimen of $R$. enfurnada, $218.6 \mathrm{~mm}$ SL, shows signs of age, including emaciation and arched backbone, probably being close to maximum size of species (Fig. 3).

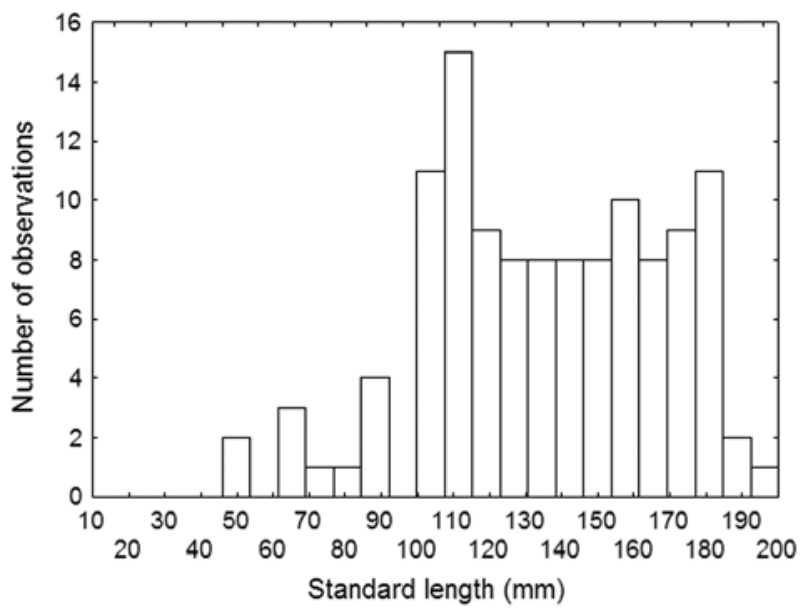

Fig. 2. Distribution of standard length $(\mathrm{mm})$ classes relative to 121 individuals of $R$. enfurnada. Data collected in July 2005. 
Mouth terminal, upper jaw slightly in advance of lower jaw. Rictal folds well developed, reaching or slightly surpassing posterior margin of orbit. Premaxilla with single band of small, conic teeth in 10 irregular tooth rows, its posterolateral corners rounded, not produced. Dentition of lower jaw similar to that of premaxilla, in six irregular tooth rows. Palatine and vomer edentulous. Maxillary barbel long, reaching origin of anal fin in smaller specimens, and between middle and tip of depressed pelvic fin in larger individuals. Mental barbels long, inner-mental barbel surpasses posterior border of branchial membrane, almost reaching pectoral-fin insertion; outer-mental barbel reaching tip of depressed pectoral fin. Inner mentalbarbel base inserted slightly in advance of outer mental-barbel base. Anterior nares tubular, near border of snout; posterior nares tubular (incomplete in some specimens) and short, with rounded openings; internarial length less than width between posterior nares. Eye variable in size (Fig. 4). Branchial membranes touching midventrally, but not overlapping (except in largest examined specimen, where membranes slightly overlap), and united to isthmus only anteriorly. Anus and urogenital papilla separated; urogenital papilla conspicuous and variable in size and shape, from short and triangular to elongate, located at midlength between bases of anal and pelvic fins.
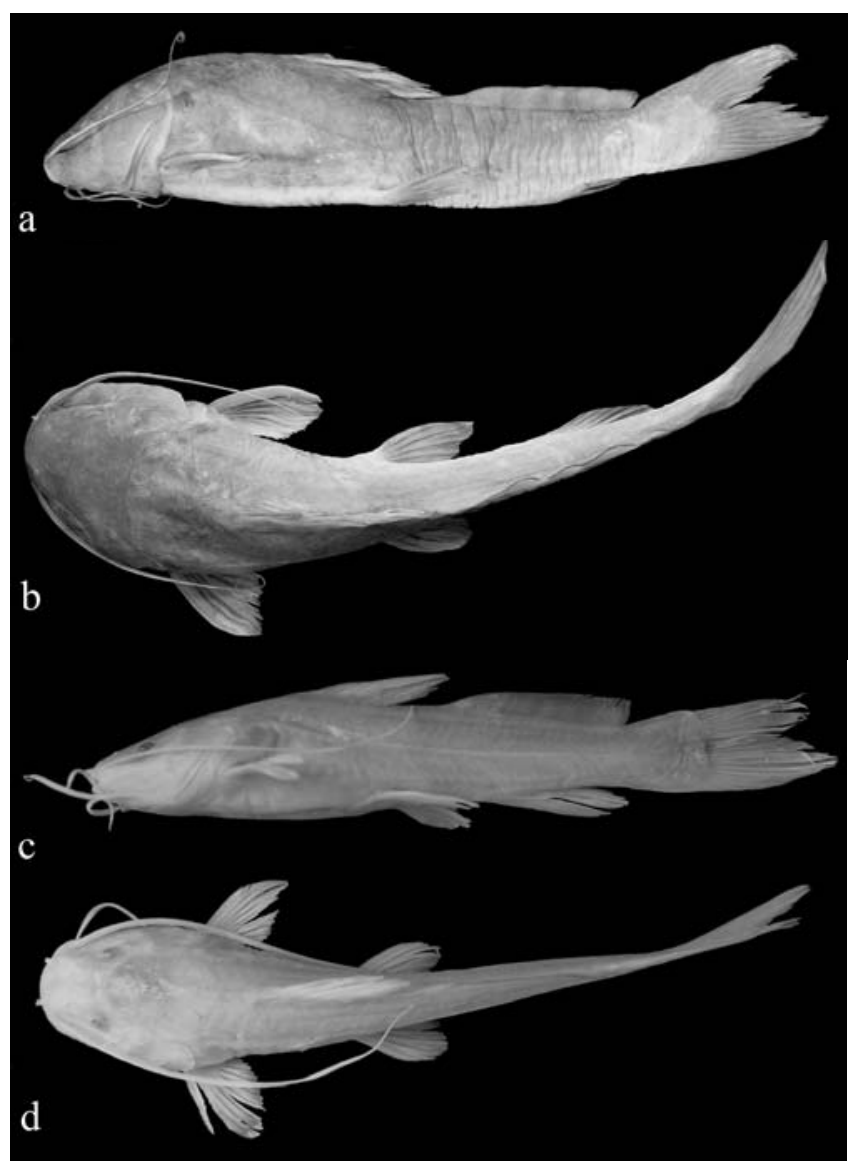

Fig. 3. Lateral and dorsal views of large $(218.6 \mathrm{~mm} \mathrm{SL}$; $\mathbf{a}$ and $\mathbf{b}$, respectively; MZUSP 87777) and small (61.2 $\mathrm{mm} \mathrm{SL}$; c and d, respectively; LIRP 5643) individuals of $R$. enfurnada.
Dorsal fin with i,I,7 rays. Dorsal spine weakly developed, smooth, without serrae, comparatively short, its length 39.6$77.7 \%$ of dorsal-fin height. Adipose fin long $(30.2-36.0 \% \mathrm{SL})$, its origin at vertical through middle of depressed pelvic fin, and its end slightly posterior to end of depressed anal fin. Adipose fin with slightly convex dorsal margin and conspicuous posterior free lobe. Caudal fin forked, ventral lobe slightly longer than dorsal; ventral lobe rounded in most individuals, pointed in some small specimens, dorsal lobe variable, pointed (in most small fish) to rounded. Dorsal lobe of caudal fin with i,7 and ventral lobe with i,8 principal rays. Anal fin with v,7-8 rays; its margin rounded in most specimens, pointed in some small fishes.

Pectoral fin with I,9 rays. Pectoral spine well developed, depressed, elliptical in transversal section, its anterior margin with 4-5 retrorse serrae distally and 7-13 small serrae proximally, posterior margin distinctly serrated (Fig. 5). First branched pectoral-fin ray longest, other branched rays decreasing in length posteriorly. Posterior cleithral process relatively long, strong, reaching one-third of depressed pectoral fin (Fig. 1c). Pelvic fin with i,5 rays, its origin at vertical through end of dorsal-fin base, pointed in smaller specimens, rounded in larger ones.

Skull roof (Fig. 6) with wide, elongated anterior cranial fontanel; mesethmoid contacts frontal posteriorly on either side of concavity formed by anterior fontanel; frontal broad, greatest width equal to length, meeting posteriorly along $1 / 4$

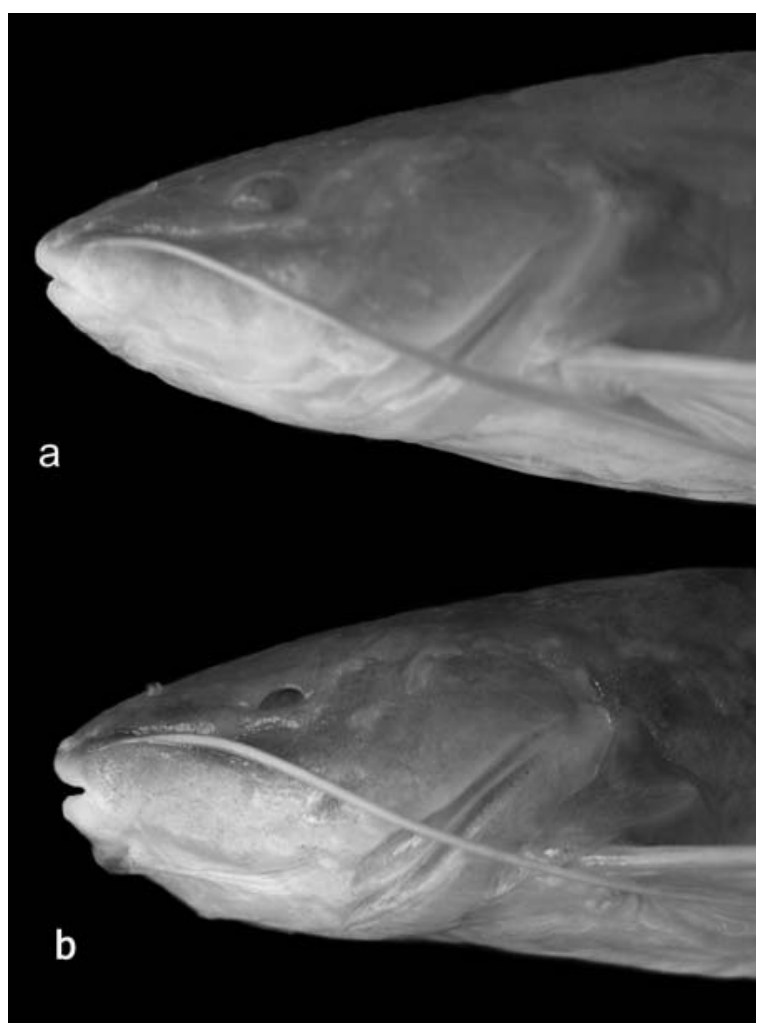

Fig. 4. Eye size variability of two paratypes of R. enfurnada; a, reduced eyes (32.9 $\mathrm{mm} \mathrm{HL})$; b, externally invisible eyes, with a conspicuous orbital concavity (32.1 mm HL); (MZUSP 87777). 
of its length. Posterior cranial fontanel reduced to elliptical foramen near center of supraoccipital. Supraoccipital process short, its length equal to length of supraoccipital bone excluding posterior process. Infraorbital bone series comprising smaller orbital cavity. Branchiostegal rays six.

In two cleared and stained specimens: 38 post-Weberian free vertebrae; nine pairs of ribs. Caudal skeleton with four hypural plates: rectangular parhypural; triangular hypurals $1+2$; triangular hypurals $3+4$, triangular hypural 5 .

Color in alcohol. Specimens light gray to yellowish; base of dorsal fin, margin of adipose and dorsal fins slightly duskier, especially in darker fish; faint lateral stripe in darker fish, usually interrupted; melanophores concentrated on pseudotympanum in some specimens (not related to general degree of pigmentation); body coloration pattern otherwise homogeneous, pectoral, pelvic, anal, and caudal fins light colored. Melanophores concentrated on top of head and, in 11 out of 20 fish, also behind orbit, forming dark spot slightly larger than orbit. Density of melanophores in three cave and in three epigean specimens, respectively: 22.4, 28.8, and 30.4 melanophores per $\mathrm{mm}^{2}$ in Rhamdia enfurnada, and 43.2, 46.4, and 51.2 melanophores per $\mathrm{mm}^{2}$ in Rhamdia cf. quelen, from same river basin (MZUSP 54640).

Color in life. Light gray to yellowish, with melanophores concentrated on head region and margins of adipose and dorsal fins. Iridophores present, concentrated on opecular region, forming yellowish iridescent spot covering $2 / 3$ of this region.

Distribution. Known only from its type locality, the Gruna do

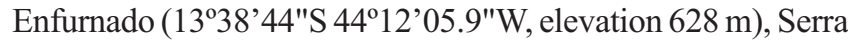
do Ramalho, Bahia State, middle São Francisco River basin, northeastern Brazil.

Etymology. From Gruna do Enfurnado, the name of the type locality, meaning shut, hidden, or isolated in a cave or cavern.

Habitat description. The Gruna do Enfurnado comprises 7,560 $\mathrm{m}$ of mapped passageways. This cave has about $3,000 \mathrm{~m}$ of subterranean streams and pools, with two main permanent reaches respectively at the proximal and distal ends of the cave. Flash floods occur in the rainy season, connecting these reaches; during the dry season, several pools of different sizes become isolated between them. The depth during the

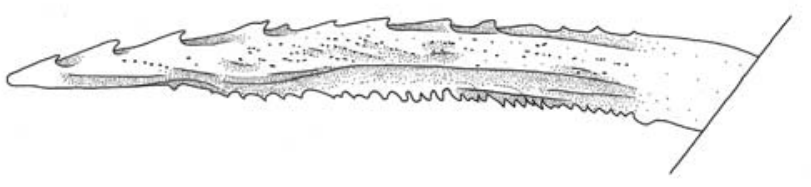

Fig. 5. Left pectoral fin spine of $R$. enfurnada showing the anterior margin with four retrorse dentations (MZUSP 87779). Scale bar, $2.5 \mathrm{~mm}$. Drawing: F. D. Passos. dry season varied from less than $0.2 \mathrm{~m}$ to $2-3 \mathrm{~m}$ in the large pools. Large amounts of organic matter are present. The fishes are especially abundant in the downstream reach, at the far end of the cave. Physico-chemical water variables measured with a digital Horiba apparatus in a deep pool at the proximal stream reach, respectively in September 2003 (end of the dry season) and July 2005 (middle of the dry season), were: temperature $=20.5^{\circ} \mathrm{C} / 21.5^{\circ} \mathrm{C} ; \mathrm{pH}=7.47 / 8.25$; conductivity $=$ $0.597 \mathrm{~ms} \mathrm{~cm}^{-1} / 0.711 \mathrm{~ms} \mathrm{~cm}^{-1}$; dissolved oxygen (DO) $=0.39$ $\mathrm{mg} \mathrm{l}^{-1} / 0.54 \mathrm{mg} \mathrm{l}^{-1}$; salinity $=0.02 \% / 0.03 \%$. The low values of DO measured in the dry season may have been due to the accumulation of organic matter associated to the slow movement of water. Several healthy catfishes were found in the pool, indicating a high tolerance to hypoxia in the species. The high $\mathrm{pH}$ and conductivity values are typical of karst waters. The average annual temperature in the region is $25^{\circ} \mathrm{C}$,

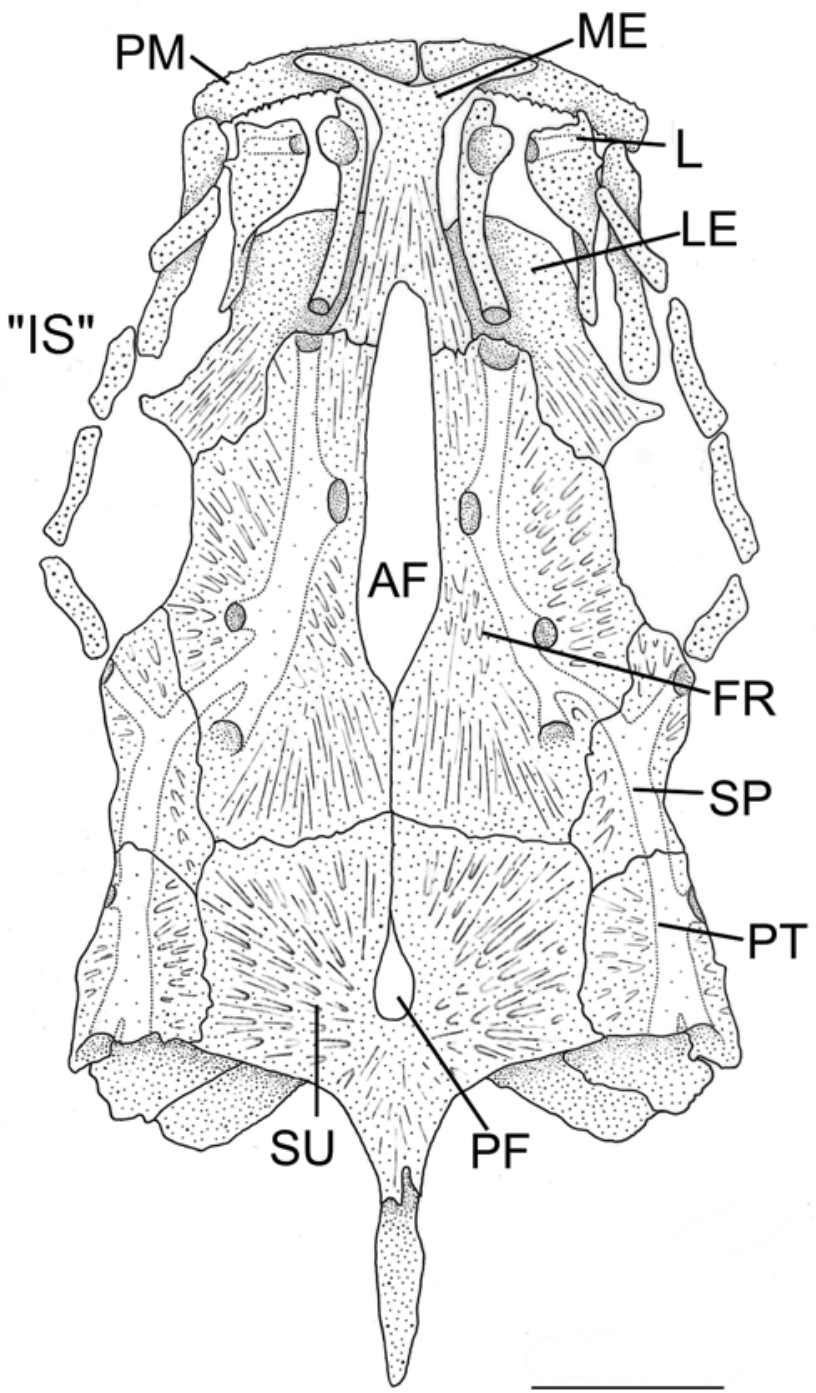

Fig. 6. Dorsal view of the neurocranium of $R$. enfurnada (MZUSP 87779). AF, anterior fontanel; "IS", infraorbital bone series; FR, frontal; L, lachrymal; LE, lateral ethmoid; ME, mesethmoid; PF, posterior fontanel; PM, premaxilla; PT, pterotic; SP, sphenotic; SU, supraoccipital. Scale bar $2.5 \mathrm{~mm}$. Drawing: F. D. Passos. 
Table 1. Morphometric data of holotype (H) and paratypes of Rhamdia enfurnada from Gruna do Enfurnado, Bahia State, northeastern Brazil ( $\mathrm{n}=20$, including holotype) and Rhamdia $\mathrm{cf}$. quelen (MZUSP 54640 and MZUSP 37979) from São Francisco River basin (n=19). SD, standard deviation.

\begin{tabular}{lccccc}
\hline & \multicolumn{4}{c}{ Paratypes } & \multicolumn{2}{c}{ Rhamdia cf. quelen } \\
& $\mathrm{H}$ & Range & Mean \pm SD & Range & Mean \pm SD \\
\hline Standard length (mm) & 137.8 & $43.8-218.6$ & $88.5 \pm 46.38$ & $63.8-263.6$ & $101.7 \pm 46.27$ \\
& Percent of Standard length & & & \\
Head length & 24.2 & $23.1-27.0$ & $25.2 \pm 1.11$ & $24.1-30.3$ & $25.7 \pm 1.43$ \\
Head width & 21.1 & $21.1-24.5$ & $22.6 \pm 0.87$ & $18.7-21.5$ & $20.4 \pm 0.80$ \\
Mouth width & 11.5 & $10.7-15.6$ & $12.0 \pm 1.03$ & $9.1-14.1$ & $11.4 \pm 1.08$ \\
Body depth & 19.9 & $17.1-23.7$ & $20.7 \pm 1.67$ & $17.0-22.7$ & $19.2 \pm 1.27$ \\
Body width & 89.3 & $83.5-94.8$ & $89.2 \pm 3.25$ & $44.7-93.6$ & $79.74 \pm 9.57$ \\
Predorsal length & 35.4 & $33.5-40.1$ & $36.2 \pm 1.60$ & $35.4-40.6$ & $36.8 \pm 1.17$ \\
Maxillary barbel length & 49.9 & $39.7-83.3$ & $60.7 \pm 9.73$ & $53.0-85.0$ & $69.7 \pm 9.14$ \\
Outer mental barbel length & 24.9 & $21.3-30.5$ & $26.1 \pm 2.62$ & $20.6-35.0$ & $26.8 \pm 4.20$ \\
Inner mental barbel length & 17.4 & $14.1-27.5$ & $18.5 \pm 2.77$ & $12.8-20.3$ & $16.7 \pm 2.21$ \\
Pectoral fin length & 13.9 & $13.9-17.6$ & $15.0 \pm 1.09$ & $14.2-17.5$ & $15.6 \pm 1.01$ \\
Dorsal fin height & 11.8 & $10.5-19.6$ & $13.9 \pm 2.65$ & $9.4-16.8$ & $12.1 \pm 1.56$ \\
Adipose fin length & 34.9 & $30.2-36.0$ & $33.9 \pm 1.38$ & $30.8-37.3$ & $34.6 \pm 2.05$ \\
Anal fin base & 8.9 & $7.4-13.6$ & $10.0 \pm 1.77$ & $7.2-10.1$ & $8.8 \pm 0.85$ \\
Anal origin to caudal base & 32.1 & $29.3-36.0$ & $32.6 \pm 1.79$ & $27.9-33.5$ & $32.2 \pm 15.63$ \\
Caudal peduncle length & 21.3 & $17.9-23.1$ & $20.7 \pm 1.18$ & $17.0-22.7$ & $20.0 \pm 2.73$ \\
& Percent of Head length & & & \\
Interorbital width & 43.9 & $38.9-52.2$ & $42.3 \pm 3.21$ & $33.3-43.7$ & $36.1 \pm 4.64$ \\
Orbital diameter & 9.5 & $6.4-13.6$ & $11.4 \pm 1.74$ & $14.5-24.4$ & $21.3 \pm 6.59$ \\
Snout length & 42.5 & $38.9-46.4$ & $42.9 \pm 2.04$ & $38.7-43.9$ & $39.5 \pm 6.85$ \\
& Other proportions & & & \\
Dorsal spine length:Dorsal fin heigth & 73.2 & $39.6-77.7$ & $59.4 \pm 11.89$ & $46.3-91.6$ & $61.7 \pm 12.1$ \\
Pectoral spine length:Pectoral fin length & 88.6 & $60.7-91.9$ & $75.4 \pm 9.80$ & $45.7-74.9$ & $62.4 \pm 7.64$ \\
Caudal peduncle depth:Caudal peduncle length & 48.9 & $44.3-58.6$ & $52.3 \pm 3.86$ & $48.7-66.0$ & $58.3 \pm 8.80$ \\
\hline
\end{tabular}

thus the measured water temperatures were lower than expected since, due to the thermal isolation, the temperature in subterranean habitats usually follow the annual mean temperature.

Notes on ecology and behavior. Rhamdia catfishes were distributed throughout the cave, from shallow, pebble-bottomed reaches, where smaller fish concentrate and may attain densities of 10 individuals $\mathrm{m}^{-2}$, to deep, slow-moving, soft-bottomed pools, where we found the larger specimens. The largest numbers of fishes were found at the distal permanent stream reach (around 150 individuals observed along the 600 m reach in July 2005 - Trajano \& Bichuette, unpubl. data). A mark-recapture study is in progress aiming to estimate the population size, minimal extension of catfish movements and life cycle parameters. Examination of the stomach contents of the two cleared and stained individuals revealed a diet of invertebrates, mainly arthropods, including terrestrial items (fragments of Diplopoda and Ensifera fallen accidentally or washed into the water) and a great amount of detritus.

The catfish behavior was directly observed in the cave habitat. In addition, seven specimens were brought alive to the laboratory and kept collectively in a 100-1 aquarium in a dark room. Like other troglobitic siluriforms (e.g., P. kronei, Taunayia sp., the new heptapterid genus from Chapada Diamantina, and the undescribed Trichomycterus species from Bodoquena and Serra do Ramalho, respectively Trichomycterus sp. 2 and 3 in Trajano, 2003), Rhamdia enfurnada exhibited an increased midwater activity when compared to their typically bottom-dwelling epigean relatives. Hiding places made of limestone blocks were available; the catfish exhibited variable cryptobiotic behavior, with smaller individuals hiding less frequently than the larger ones. The reduction of cryptobiotic habits is another difference in relation to epigean relatives shared by several unrelated troglobitic siluriforms (Trajano, 2003).

The catfishes from Gruna do Enfurnado reacted to sudden illumination with flashlights and noise with increased swimming activity, which indicates that these catfishes perceive these stimuli. In reaction to light experiments, using choice-chamber (as those described in Trajano \& Gerhard, 1997, among others), these catfishes were mostly indifferent to light, i.e., they did not show significant preferences, either to the dark chamber or to the illuminated one (A.C. Barbosa, unpubl. data).

The catfishes from Gruna do Enfurnado were moderately aggressive under laboratory conditions: when two individuals met, apparently by chance (no spontaneous active pursuing was observed), usually the larger one chased away the smaller, in a quick pursuit, or the smaller fish rapidly avoided the other one, without pursuing. These interactions were usually observed during feeding with living Artemia, when increased activity enhanced the chances of meeting, and may be mostly related to competition for food. Nevertheless, as expected in view of the high population densities observed in the cave, in general the catfish seemed to be quite tolerant to the proximity of conspecifics, since no individual exhibited clear signals of stress, even after having been kept together for one and one-half years. Weak, size-related dominance was mostly displayed in relation to food and hidden places. 


\section{Discussion}

The monophyly of Rhamdia is not yet established. Bockmann (1998) placed two representative species of the Heptapteridae, $R$. quelen and $R$. laticauda, in a paraphyletic sequence, with the latter as sister-group to Pimelodella. Perdices et al. (2002), analyzing mitochondrial DNA, elucidated the relationship of Mesoamerican Rhamdia. In that paper, the monophyly of three trans-Andean taxa, $R$. guatemalensis, $R$. laticauda and $R$. cinerascens, was strongly supported. Those authors also proposed that the representatives of $R$. quelen from Mesoamerican are phylogenetically distinct from South American individuals (opposite of that proposed by Silfvergrip, 1996). The inclusion of Rhamdia enfurnada in this genus was based on its general appearance, the reduced posterior fontanel and the short supraoccipital process (Eigenmann \& Eigenmann, 1890).

Rhamdia enfurnada possesses typical reductive character states in common with the other exclusively subterranean species and populations of the genus. Such troglomorphisms, which distinguish these catfishes from the epigean ones found in the São Francisco River basin (Rhamdia cf. quelen - MZUSP 54640 and 37979), include the reduction of the eyes (orbital diameter in relation to head length, 6.4-3.6\% in $R$. enfurnada vs. $14.5-24.4 \%$ in the examined epigean specimens) and of the dark pigmentation as expressed by the low density of melanophores (22.4-30.4 melanophores per $\mathrm{mm}^{2}$ in $R$. enfurnada vs. 43.2-51.2 melanophores per $\mathrm{mm}^{2}$ in epigean specimens comparison of densities of melanophores in epigean and cave specimens indicates that the weaker pigmentation in $R$. enfurnada was due, at least in part, to an evolutionary reduction in density of melanophores), both characters highly variable in the studied population.

In addition, morphometric characters are distinctive for these two species ( $R$. enfurnada compared to Rhamdia $c f$. quelen), significantly different: head width:SL $(\mathrm{t}=8.28$, $\mathrm{p}<0.001)$; maxillary-barbel length:SL $(\mathrm{t}=-2.97, \mathrm{p}=0.005)$; inner mental-barbel length:SL $(\mathrm{t}=2.19, \mathrm{p}=0.035)$; interorbital width:HL $(\mathrm{T}=223.5, \mathrm{p}<0.001)$; orbital diameter:HL $(\mathrm{t}=-13.64$, $\mathrm{p}<0.001)$; dorsal-fin height:SL $(\mathrm{T}=280.0, \mathrm{p}=0.039)$; pectoralfin spine length:pectoral-fin length $(\mathrm{t}=4.58, \mathrm{p}<0.001)$; anal-fin base:SL ( $\mathrm{T}=294.0 ; \mathrm{p}=0.016)$; anal origin to caudal base:SL $(\mathrm{T}=293.0, \mathrm{p}=0.015)$ and caudal-peduncle depth:caudal-peduncle length ( $\mathrm{t}=-3.39, \mathrm{p}=0.002)$ (Fig. 7).

The shorter maxillary barbel in R. enfurnada than in Rhamdia cf. quelen is rather unexpected since an emphasis on non-visual sensory organs is predicted for subterranean animals. In fact, the elongation of structures bearing chemo- and mechanosensory organs is common among troglobites. This is the case of the Mexican troglobitic Rhamdia species, $R$. reddelli, $R$. zongolicensis, $R$. laluchensis and $R$. macuspanensis, which have maxillary, inner-mental and outer-mental barbels longer than those of the epigean closest relative, $R$. laticauda (Weber et al., 2003). On the other hand, like $R$. enfurnada, Pimelodella kronei tended to have maxillary barbels shorter than the epigean putative sister-species, $P$. transitoria. In this case, it has been suggested that agonistic encounters, frequently leading to barbel injuries, could explain a considerable number of individuals with regenerating barbels in the cave species (Trajano \& Britski, 1992). Rhamdia enfurnada is much less aggressive than $P$. kronei, hence this explanation does not seem to apply to the former. For the moment, we do not have any explanation for the apparently shortened barbels in $R$. enfurnada.

In comparison to other troglobitic Rhamdia species, $R$. enfurnada has a lower degree of troglomorphy regarding eyes and pigmentation, which are highly variable. Rhamdia reddelli is described as lacking eyes (with only one specimen showing a tiny eye spot) and with almost no pigmentation (Miller, 1984); likewise, R. macuspanensis and R. laluchensis as having rudimentary eyes, covered with skin and not visible externally, and with reduced body pigmentation (Weber \& Wilkens, 1998; Weber et al., 2003). Rhamdia zongolicensis is also almost devoid of dark pigmentation, but the eyes are less reduced than in $R$. reddelli (Wilkens, 1993). Rhamdia quelen urichi (as referred by Weber et al., 1998, and Romero \& Paulson, 2001), from Trinidad, also does not have any trace of eyes externally, but the body coloration is described as pale yellowish brown (Norman, 1926). In our opinion, the described differences do support a species status for this taxon, which should be referred as R. urichi. Rhamdia guasarensis, the only troglobitic species from South America, is particularly specialized, characterized, among others, by a concave dorsal profile of head and widened cutaneous pores of the cephalic laterosensory system, which may be related to sensorial compensation mechanisms, in addition to a complete

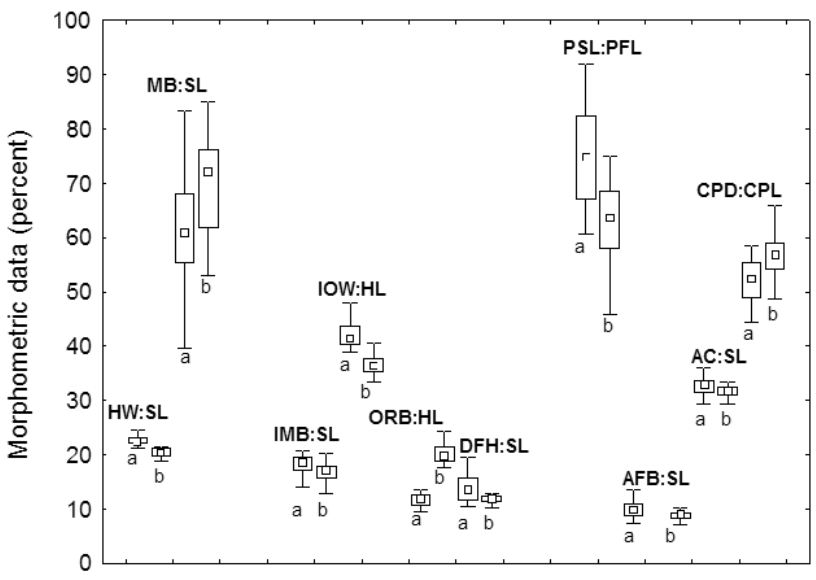

Fig. 7. Boxplots showing the proportions of R. enfurnada (a) and Rhamdia cf. quelen (b) found to be significantly different. HW:SL (head width:standard length), MB:SL (maxillary barbel length:standard length), IMB:SL (inner mental barbel length:standard length), IOW:HL (interorbital width:head length), ORB:HL (orbital diameter:head length), DFH:SL (dorsal fin height:standard length), PSL:PFL (pectoral-spine length:pectoral fin length), AFB:SL (anal-fin base length:standard length), AC:SL (anal origin to caudal base:standard length), CPD:CPL (caudal-peduncle depth:caudal peduncle length). 
absence of pigmentation and eyes (DoNascimiento et al., 2004). Variability in development of eyes and pigmentation as in $R$. enfurnada was only reported for Rhamdia laticauda typhla, from Belize ["Reduction of eyes to various degrees is evident... Some individuals have very small, deep pits each with a small black spot at the bottom....A few individuals have larger eyes (about one-half ... the normal eye size of $R$. laticauda laticauda...]"... "There is considerable variation in body coloration..., with some individuals being almost white and others tending to be a dark brown." - Greenfield et al., 1982). No author mentions iridescence in these species, thus the presence of iridophores may be unique to R. enfurnada.

Following Perdices et al. (2002), the troglomorphic Rhamdia species found in caves of Mexico and Belize belong to the trans-Andean laticauda and guatemalensis clades, which forms a monophyletic group with cinerascens clade. Thus, differences between $R$. enfurnada (that probably belong to the cis-Andean quelen group) and these species, such as those concerning the pectoral spine (serrae present in both margins of the pectoral spine $v s$. strong serrae present in the posterior margin of the pectoral spine and anterior margin smooth), the maxillary barbel (relatively longer in $R$. enfurnada) and mithocondrial DNA are likely to reflect different epigean ancestry.

Willkens (1986) proposed a correlation between the degree of morphological reduction and the time of subterranean evolution based on the neutral mutation model (Wilkens, 1988, 2005). From this, it may be concluded that $R$. enfurnada, which presents highly variable eyes and body pigmentation, has been isolated in the subterranean environment for a relatively short time when compared to other cave Rhamdia species (except $R$. laticauda typhla). On the other hand, $R$. enfurnada exhibits a reduction in the cryptobiotic habits and an important midwater and surface activity, which are considered apomorphic, advanced traits for troglobitic catfishes (Trajano \& Bockmann, 1999).

The population density (preliminarily estimated in $0.1-0.2$ individuals $\mathrm{m}^{-2}$ in average, and reaching 10 individuals $\mathrm{m}^{-2}$, in the dry season (E. Trajano and M.E. Bichuette, unpubl. data) and size (several thousands of individuals) of R. enfurnada may the considered high for cave-fish standards (Trajano, 2001a). This may be related to the large amounts of organic matter as detritus deposited by flash floods during the rainy season and providing an abundant source of food directly for the catfishes (one examined stomach had a considerable amount of detritus) and for their prey. During a two-day visit, in July 2005, ca.120 fishes were captured and measured, of which 100 were marked and released. This represents quite a large number for a troglobitic fish, only comparable to the armored catfish, Ancistrus cryptophthalmus (Loricariidae), among the studied Brazilian cave siluriforms. On the other hand, contrary to the observed for Ancistrus (Trajano, 2001b), the few data on population density of epigean Rhamdia catfishes point to much lower numbers (0.032-0.041 individuals $\mathrm{m}^{-2}$, L.F. Duboc, unpubl. data).

It noteworthy that the distribution of size classes, shown in Fig. 2, is not normal, but skewed toward larger size/age classes. The same tendency was observed for Pimelodella kronei (Trajano \& Britski, 1992), but not for P. speleae, which exhibited a normal distribution of classes of size (Trajano et al., 2004). Age distributions skewed toward larger classes were also observed for specialized troglobitic amblyopsid fishes (Culver, 1982), and is evidence of a K-selected life cycle (precocial lifestyle, sensu Balon 1981, 1999), a common trait of troglobites (Culver, 1982). Rhamdia enfurnada is among the largest troglobitic fishes in the world.

The Serra do Ramalho karst area is not protected by law. Nowadays, the accelerated extraction of the original vegetation for cotton and soybean cultivation represents a main threat. Thus, there is reason for major concern about the future of this endemic species (despite the large population size). A proposal of a conservation unit including the Gruna do Enfurnado system is urgently needed to assure its protection.

Comparative material. Rhamdia hilarii (Rhamdia $\mathrm{cf}$. quelen sensu Silfvergrip, 1996), MZUSP 37979, Brazil, Minas Gerais, município de São Francisco, Três Marias hydroelectric dam, São Francisco River. Rhamdia cf. quelen, MZUSP 54640, Brazil, Minas Gerais, município de Bocaiúva, creek tributary to the Jequitaí River, São Francisco basin. Pimelodella spelaea, MZUSP 81726, Brazil, Goiás, município de São Domingos, Gruta São Bernardo, upper Tocantins River basin. Taunayia sp., MZUSP unreg. (1ex.), Brazil, Bahia, município de Campo Formoso, Toca do Gonçalo, middle São Francisco River basin. Heptapteridae unnamed species, MZUSP unreg. (2 exs.), Brazil, Bahia, município de Itaetê, Lapa do Bode, Paraguaçú River basin.

\section{Acknowledgments}

We are grateful to the Bambui Speleological Association for information on the new species, especially to E. Rubbioli, L. Senna-Horta, and V. Moura for the first information and pictures of Rhamdia enfurnada; for valuable help during fieldwork - E. Rubbioli, R. Brandi, U. Corrêa, and F. Valentim Von Tein; for the loan of comparative material - Osvaldo Oyakawa from MZUSP. F. D. Passos has made the drawings. The Fundação de Amparo à Pesquisa do Estado de São Paulo (Process 2003/00794-5) and CNPq (grant number 306066/882) provided support for the fieldwork. All Catfish Species Inventory (ACSI) supported part of the present work (NSF DEB-0315963). Permission for collecting species was granted by IBAMA.

\section{Literature cited}

Balon, E. K. 1981. Saltatory processes and altricial to precocial forms in the ontogeny of fishes. American Zoologist, 21:573-596.

Balon, E. K. 1999. Alternative ways to become a juvenile or a definitive phenotype (and on some persisting linguistic offenses). Environmental Biology of Fishes, 56: 17-38. 
Baptista, R. L. C. \& A. P. L. Giupponi. 2003. A new troglomorphic Charinus from Minas Gerais State, Brazil (Arachnida: Amblypygi: Charinidae). Revista Ibérica de Aracnología, 7: 79-84.

Bichuette, M. E. \& E. Trajano. 2003. Epigean and subterranean ichthyofauna from São Domingos karst area, upper Tocantins river basin, Central Brazil. Journal of Fish Biology, 63(5): 1100-1121.

Bockmann, F. A. 1994. Description of Mastiglanis asopos: a new pimelodid catfish genus from northern Brazil, with comments on phylogenetic relationships inside the subfamily Rhamdiinae (Siluriformes: Pimelodidae). Proceedings of the Biological Society of Washington, 107: 760-777.

Bockmann, F. A. 1998. Análise filogenética da família Heptapteridae (Teleostei, Ostariophysi, Siluriformes) e redefinição de seus gêneros. Unpublished Ph.D. Dissertation, Universidade de São Paulo, São Paulo.

Culver, D. C. 1982. Cave life: evolution and ecology. Harvard University Press, Cambridge. 189 p.

Do Nascimiento, C., F. Provenzano \& J. G. Lundberg. 2004. Rhamdia guasarensis (Siluriformes: Heptapteridae), a new species of cave catfish from the Sierra de Perijá, northwestern Venezuela. Proceedings of the Biological Society of Washington, 117(4): 564-574.

Eigenmann, C. H. \& R. S. Eigenmann. 1890. A revision of the South American Nematognathi or cat-fishes. Occasional Papers of the California Academy of Sciences, 1: 1-508.

Greenfield, D. W., T. A. Greenfield \& R. L. Woods. 1982. Anew subspecies of cave-dwelling pimelodid catfish, Rhamdia laticauda typhla from Belize, Central America. Brenesia, 19/20: 563-576.

Lundberg, J. G. \& L. McDade. 1986. On the South American catfish Brachyrhamdia imitator Myers (Siluriformes, Pimelodidae), with phylogenetic evidence for a large intrafamilial lineage. Notula Naturae, 463: 1-24.

Miller, R. R. 1984. Rhamdia reddelli, new species, the first blind pimelodid catfish from Middle America, with a key to the Mexican species. Transactions of the San Diego Society of Natural History, 20(8): 135-144.

Perdices, A., E. Bermingham, A. Montilla \& I. Doadrio. 2002. Evolutionary history of the genus Rhamdia (Teleostei: Pimelodidae) in Central America. Molecular Phylogenetics and Evolution, 25: 172-189.

Pérez, A. \& A. B. Kury. 2002. A new remarkable troglomorphic gonyleptid from Brazil (Arácnida, Opiniones, Laniatores). Revista Ibérica de Aracnología, 5: 43-50.

Romero, A. \& K. M. Paulson. 2001. It's a wonderful hypogean life: a guide to the troglomorphic fishes of the world. Pp. 13-41 In: A. Romero (Ed.). The biology of hypogean fishes. Kluwer Academic Publ., Dordrecht. 364 p.

Silfvergrip, A. M. C. 1996. A systematic review of the Neotropical catfish genus Rhamdia (Teleostei, Pimelodidae). Swedish Museum of Natural History, Stockholm. 156 p.

Taylor, W. R. \& G. A. Van Dyke. 1985. Revised procedures for staining and clearing small fishes and other vertebrates for bone and cartilage study. Cybium, 9: 107-119.
Trajano, E. 1991. Populational ecology of Pimelodella kronei, troglobitic catfish from southeastern Brazil (Siluriformes, Pimelodidae). Environmental Biology of Fishes, 30: 407-21.

Trajano, E. 2001a. Ecology of subterranean fishes: an overview. Environmental Biology of Fishes, 62: 133-160.

Trajano, E., 2001b. Habitat and population data of troglobitic armoured cave catfishes, Ancistrus cryptophthalmus Reis 1987, from Central Brazil (Siluriformes: Loricariidae). Environmental Biology of Fishes, 62: 195-200

Trajano, E. 2003. Ecology and ethology of subterranean catfishes. Pp. 601-635 In: G. Arratia, B. G. Kapoor, M. Chardon \& R. Diogo (Eds.). Catfishes, v. 2. Science Publishers, Enfield. 844p.

Trajano, E. \& F. A. Bockmann. 1999. Evolution of ecology and behaviour in Brazilian cave Heptapterinae catfishes, based on cladistic analysis (Teleostei: Siluriformes). Mémoires de Biospéologie, 26: 123-129.

Trajano, E. \& H. A. Britski. 1992. Pimelodella kronei (Ribeiro,1907) e seu sinônimo Caecorhamdella brasiliensis Borodin, 1927: morfologia externa, taxonomia e evolução (Teleostomi, Siluriformes). Boletim de Zoologia, 12: 53-89.

Trajano, E. \& P. Gerhard. 1997 Light reaction in Brazilian cave fishes (Siluriformes: Pimelodidae, Trichomycteridae, Loricariidae). Mémoires de Biospéologie, 24: 127-138.

Trajano, E., R. E. Reis \& M. E. Bichuette. 2004. Pimelodella spelaea, a new cave catfish from Central Brazil, with data on ecology and evolutionary considerations (Siluriformes: Heptapteridae). Copeia, 2004(2): 315-325.

Weber, A., G. S. Proudlove, J. Parzefall, H. Wilkens \& T. T. Nalbant. 1998. Pisces (Teleostei). Pp. 1179-1190 In: C. Juberthie \& V. Decu (Eds.). Encyclopaedia Biospeologica, Tome II. Société de Biospéologie, Moulis-Bucarest. 1373p.

Weber, A., G. Allegrucci \& V. Sbordoni. 2003. Rhamdia laluchensis, a new species of troglobitic catfish (Siluriformes: Pimelodidae) from Chiapas, Mexico. Ichthyological Exploration of Freshwaters, 14(3): 273-280.

Weber, A. \& H. Wilkens. 1998. Rhamdia macuspanensis: a new species of troglobitic pimelodid catfish (Siluriformes: Pimelodidae) from a cave in Tabasco, Mexico. Copeia, 1998(4): 998-1004.

Wilkens, H. 1986. The tempo of regressive evolution: studies of the eye reduction in stygobiont fishes and decapod crustaceans of the Gulf Coast and West Atlantic region. Stygologia, 2(1/2): 131-143.

Wilkens, H. 1988. Evolution and genetics of epigean and cave Astyanax fasciatus (Characidae, Pisces). Evolutionary Biology, 23: 271-367.

Wilkens, H. 1993. A new species of Rhamdia (Pisces: Pimelodidae) from a cave in the Sierra de Zongolica (Veracruz, Mexico). Mitteilungen aus dem Hamburgischen Zoologischen Museum und Institut, 90: 375-378.

Wilkens, H., 2005. Neutral mutation. Pp. 411-415 In: D. C. Culver \& W. White (Eds.). The Encyclopedia of Caves. Academic Press, San Diego. 680p.

Received August 2005 Accepted November 2005 